\title{
A FUZZY INFERENCE APPROACH TO SUPPLIER SEGMENTATION FOR STRATEGIC DEVELOPMENT
}

\author{
G. Rajesh ${ }^{1 *} \&$ R. Raju
}

\section{ARTICLE INFO}

Article details

Submitted by authors 16 Nov 2019

Accepted for publication 24 Feb 2021

Available online $\quad 28$ May 2021

\section{Contact details}

Corresponding author

rajeshg@crescent.education

\section{Author affiliations}

1 Department of Mechanical Engineering, B.S.A. Crescent

Institute of Science and

Technology, India

2 Department of Industrial Engineering, Anna University, Chennai, India

\# The author was enrolled for an $\mathrm{PhD}$ degree in the Department of Industrial Engineering, Anna University, Chennai, India

\section{ORCID® identifiers}

G. Rajesh

https://orcid.org/0000-0002-5936-4111

R. Raju

https://orcid.org/0000-0003-4648-2618

\section{ABSTRACT}

A company embracing an agile strategy to win business must increase its agility and that of its strategic suppliers. Segmentation is an important tool for selecting suppliers that can be developed. This paper addresses the challenge of selecting suppliers in order to develop their agility. A novel segmentation of strategic suppliers is done on the dimensions of agility capability and business excellence. The cascaded fuzzy inference system is the tool used to assess the dimensions of agility capability and business excellence and to construct a segmentation matrix. The strategic segmentation matrix helps to identify suppliers that the company can develop.

\section{OPSOMMING}

'n Onderneming wat ' $\mathrm{n}$ ratse strategie aanneem moet sy eie ratsheid en die van sy strategiese verskaffers verbeter. Segmentering is 'n belangrike tegniek om verskaffers wat ontwikkel kan word te kies. Hierdie artikel spreek die uitdaging van verskaffer seleksie aan met die oog daarop om hul ratsheid te ontwikkel. 'n Nuwe segmenteringstegniek van strategiese verskaffers is gedoen aan die hand van die dimensies van ratsheidsvermoë en besigheidsvernuf. ' $n$ Kaskade wasigheidsinferensie stelsel is gebruik om die dimensies van ratsheidsvermoë en besigheidsvernuf te assesseer en om 'n segmenteringsmatriks te konstrueer. Die strategiese segmenteringsmatriks dra by tot die identifisering van verskaffers wat die onderneming kan ontwikkel.

\section{INTRODUCTION}

More than 50 percent of manufacturing company expenditure is on purchased inputs. Since companies focus more on their core competencies, this percentage is increasing. So suppliers have a great influence on the technology, quality, cost, and delivery of buyers' services and products, and thus on their profitability. The impact of vendors' performance on buyers' profits signifies the importance of optimising supply chain performance [1]. Numerous studies understand the vital significance of suppliers in the supply chain; thus many works on supplier selection are available in the literature. Chai, Liu and Ngai [2], Yildiz and Yayla [3], and Govindan, Rajendra, Sarkis and Murugesan [4] studied multi-criteria decision-making approaches to supplier selection, selection criteria, and industries in which case studies were conducted. Most of the reviewed articles presented a decision model for effectively selecting suppliers in different challenging situations [5].

Monitoring the performance of suppliers and enhancing their continuous improvement effort is a necessary investment for the long-term survival of companies. Supplier development (SD) is the activity of a buying organisation working in cooperation with suppliers to increase its performance and/or capabilities to satisfy companies' short and long-term supply needs [6]. Similar to supplier selection, researchers have also regarded supplier development as important recently; for example, Glock, Grosse and Ries [7] presented a literature review on papers that developed decision models for supplier development activity. One of the 
major recommendations was that, in order to assist managerial decision-making for supplier development, more quantitative models have to be developed.

An effective supplier's development programme requires, among other things, a diagnosis of the performance of current and new potential suppliers in order to identify those capabilities that need to be improved to guarantee a proper level of competitiveness. Supplier development activities may be of two types: 'indirect' or 'reactive' in which the buying firm has little or no involvement in overcoming specific performance deficiencies of the supplier; and 'direct' or 'strategic', with the buying firm being highly involved improving the supplier's long-term capabilities [8,9].

For supplier development activity, a buyer has to allocate manpower, considerable time, and technical and financial resources strategically and efficiently. The precious resources of the buyer cannot be spent randomly. A chosen group of strategic suppliers can only give good returns on the efforts of the buying company. So supplier segmentation is a necessary step towards supplier development [10, 11].

Segmenting suppliers can have two different purposes: one is for supplier management, and the other is for strategic supplier development. Kraljic's portfolio approach [12] to supplier segmentation has addressed the segmentation issue for supplier management activity very well. But very few segmentation approaches have helped the strategic supplier development activity. When a company embraces an agile, lean, or green supply chain strategy, the segmentation strategy should be oriented towards that. Further high involvement in development activity by the buying firm can happen only with its strategic suppliers. Thus segmentation for strategic supplier development warrants a tailored approach.

Previously the segmentation developed by Rezaei and Ortt [13] considered the dimensions of capability and willingness. Previous studies have considered agility as one of the supplier selection criteria [14], assessing the business impacts of the agility criterion and an order allocation strategy in multi-criteria supplier selection [15]; but segmenting strategic suppliers on their agility capability has not been considered. Therefore this study fills the gap by developing a segmentation matrix on the two dimensions of agility capability and business excellence.

The rest of the paper is organised as follows: Section 2 presents the theoretical background on supplier segmentation, the agility capability assessment, the business excellence model, and the fuzzy inference system. Section 3 discusses the details of the proposed methodology. In Section 4, a numerical example is presented to demonstrate the applicability of the model. Finally, the conclusions and future research are discussed in Section 5.

\section{THEORETICAL BACKGROUND}

\subsection{Suppliersegmentation}

A comprehensive portfolio approach to supplier segmentation was introduced by Kraljic in his seminal paper [12]. Two dimensions, profit impact and supply risk, are considered to classify materials or components into four supply categories: noncritical items, leverage items, bottleneck items, and strategic items.

Rezaei and Ortt [13] defined supplier segmentation as "The identification of the capabilities and willingness of suppliers by a particular buyer in order for the buyer to engage in a strategic and effective partnership with the suppliers with regard to a set of evolving business functions and activities in the supply chain."

They developed two new dimensions, capabilities and willingness, to segment suppliers. Rezaei and Ortt [16] segmented the suppliers of a broiler company into the dimensions of capabilities and willingness dimension, using a fuzzy analytic hierarchy process. Rezaei, Wang and Tavasszy [11] approached supplier development through segmentation, using the best-worst method for scoring suppliers' capabilities and willingness. Bai, Rezaei and Sarkis [17] introduced a methodology for green supplier segmentation, altering the willingness and capabilities dimensions for this purpose. Santos, Osiro and Lima [18] assessed suppliers using fuzzy 2-tuple, and segmented them using Rezaei and Ortt's matrix.

Lima Junior and Carpinetti [19] proposed a new methodology for evaluating supplier performance, based on the combination of fuzzy inference systems with some of the SCOR metrics. By using a two-dimensional classification grid, each supplier was categorised according to its performance in operations and cost. A 
different approach to supplier categorisation was proposed by Galo et al. [20], who combine ELECTRE TRI and hesitant fuzzy methods to categorise suppliers.

Supplier segmentation helps to allocate the quantum of resources needed to develop different types of supplier, based on their significance to the buying firm. The main advantages of using supplier segmentation are to direct the performance of suppliers with the maximum risk exposure, and to develop strategic partnerships to leverage fully the potential of the most valuable suppliers.

\subsection{Agility capability assessment}

Manufacturing companies need to survive and grow in a challenging environment of unpredictable changes driven by customers. The response to market needs has to be quick and effective. This skill of responding quickly and effectively is called 'agility'. Stachowiak and Oleśków Szłapka [21] introduced the agility capability maturity model, conceptualising agility as a capability that can be developed. The concept of continuous improvement or kaizen is widely applied across all areas of management. Agility capabilities are the company characteristics that should be created to develop the ability of the organisation to respond rapidly to changeable situations [22].

Agility capabilities consist of four main elements: responsiveness (the ability to see/identify changes, to respond quickly, and to recover), competency (the efficiency and effectiveness of a company in reaching its targets), flexibility/adaptability (the ability to implement different processes and achieve different goals with the same facilities), and quickness/speed (the ability to finish an activity in the shortest possible time)[23].

The literature (Table 1) reveals many different agile enablers or criteria. From the supplier segmentation perspective, the authors have identified 11 agile enablers that are associated with agility capabilities. An agility capability assessment framework is developed. Table 2 shows the agility capability and the enablers that help to achieve agility. A score is given to each subcategory, which can be used for assessment.

Table 1: List of agile enablers/criteria on literature

\begin{tabular}{|c|c|}
\hline Author & Agileenablers / criteria \\
\hline Wu and Barnes[24] & $\begin{array}{l}\text { Financial capability, human resource management, technology and knowledge, } \\
\text { marketing capability, industrial and organisational, competitiveness, production and } \\
\text { logistics management, partnership management. }\end{array}$ \\
\hline $\begin{array}{l}\text { Mohammady and Amid } \\
{[25]}\end{array}$ & Flexibility, speed, leanness, learning, responsive \\
\hline Soltan and Mostafa [26] & $\begin{array}{l}\text { Information integration, collaboration, process integration, market sensitiveness, } \\
\text { waste removal }\end{array}$ \\
\hline Lee, Cho and Kim [14] & $\begin{array}{l}\text { Delivery speed, delivery flexibility, make flexibility, source flexibility, agile customer } \\
\text { responsiveness, collaboration with partners, IT infrastructure }\end{array}$ \\
\hline $\begin{array}{l}\text { Vinodh and Aravindraj } \\
\text { [27] }\end{array}$ & $\begin{array}{l}\text { Status of quality, status of productivity, cost management, time management, } \\
\text { collaboration and networking, flexible volume production, seasonality, flexible } \\
\text { delivery time and locations }\end{array}$ \\
\hline $\begin{array}{l}\text { Beikkhakhian, } \\
\text { Javanmardi, Karbasian } \\
\text { and Khayambash [28] }\end{array}$ & $\begin{array}{l}\text { Delivery speed, lead time reduction, cost minimisation, quality improvement, } \\
\text { information technology, price, minimising uncertainty, logistics, customer } \\
\text { satisfaction, data accuracy }\end{array}$ \\
\hline $\begin{array}{l}\text { Kumar Potdar and Routroy } \\
{[29]}\end{array}$ & $\begin{array}{l}\text { Adaptability, product and process automation, supply chain integration, core } \\
\text { competency, supply chain key partner's alacrity, devolution of authority, information } \\
\text { visibility and transparency, manufacturing management, customer relationship } \\
\text { management, supplier relationship management, human resource management }\end{array}$ \\
\hline
\end{tabular}

Table 2: Scoring guide for agility capability assessment

\begin{tabular}{llrr}
\hline \multicolumn{1}{c}{ Category } & \multicolumn{1}{c}{ Subcategory } & Point value & Total points \\
\hline \multirow{2}{*}{ 1.Competency } & 1.1 Core competency & 150 & \multirow{2}{*}{300} \\
& 1.2 Technology & 150 & \\
\hline \multirow{3}{*}{ 2.Flexibility } & 2.1 Machine flexibility & 125 & \multirow{2}{*}{300} \\
& 2.2 Routing flexibility & 100 & \\
& 2.3 Material handling flexibility & 75 & 200 \\
\multirow{3}{*}{ 3. Responsiveness } & 3.1 Business process integration & 100 & \\
& 3.2 Empowerment & 50 & 200 \\
& 3.3 Knowledge management & 50 & \\
\hline \multirow{2}{*}{ 4.Quickness } & 4.1 Concurrent engineering & 100 & \\
& 4.2 Internal collaboration & 50 & \\
& 4.3 External collaboration & 50 & \\
\hline
\end{tabular}




\subsection{Business excellence models}

Companies that want to succeed in a competitive market aim for excellence in all their pursuits. Successful performance strategies must be learnt and practiced. Quality awards help in sharing these strategies, and provide a measure that motivates the companies to achieve excellence. The Deming Prize, the Malcolm Baldrige National Quality Award, the CII EXIM Award (India), and the Singapore Quality Award were started to evolve quality management systems and increase the competitiveness of firms [30].

The Singapore Quality Award (SQA) is based on a robust business excellence (BE) framework that allows a company to see its strengths and identify the areas for improvement, and guides it to achieve superior levels of performance. The assessment guide developed by the SQA BE framework is shown in Table 3 [31].

Table 3: Scoring guide for business excellence assessment (Singapore Quality Awards) [36]

\begin{tabular}{|c|c|c|c|}
\hline Category & Sub-category & $\begin{array}{l}\text { Point } \\
\text { value }\end{array}$ & $\begin{array}{l}\text { Total } \\
\text { points }\end{array}$ \\
\hline \multirow{3}{*}{ 1. Leadership } & 1.1 Senior leadership & 50 & \multirow{3}{*}{120} \\
\hline & 1.2 Organisational culture & 40 & \\
\hline & 1.3 Corporate governance and social responsibility & 30 & \\
\hline \multirow{3}{*}{ 2. Customers } & 2.1 Customer requirements & 30 & \multirow{3}{*}{100} \\
\hline & 2.2 Customer experience & 40 & \\
\hline & 2.3 Customer satisfaction & 30 & \\
\hline \multirow{2}{*}{ 3. Strategy } & 3.1 Strategy development & 40 & \multirow{2}{*}{80} \\
\hline & 3.2 Strategy implementation & 40 & \\
\hline \multirow{4}{*}{ 4. People } & 4.1 Human resource planning & 30 & \multirow{4}{*}{90} \\
\hline & 4.2 Employee learning and development & 20 & \\
\hline & 4.3 Employee engagement and well-being & 20 & \\
\hline & 4.4 Employee performance and recognition & 20 & \\
\hline \multirow{3}{*}{ 5. Processes } & 5.1 Innovation capabilities & 30 & \multirow{3}{*}{90} \\
\hline & 5.2 Process management & 30 & \\
\hline & 5.3 Supplier and partner management & 30 & \\
\hline \multirow{2}{*}{ 6. Knowledge } & 6.1 Knowledge management & 35 & \multirow{2}{*}{70} \\
\hline & 6.2 Analytics for performance management & 35 & \\
\hline \multirow{4}{*}{ 7. Results } & 7.1 Customer results & 110 & \multirow{4}{*}{450} \\
\hline & 7.2 Financial and market results & 120 & \\
\hline & 7.3 People results & 110 & \\
\hline & 7.4 Operational results & 110 & \\
\hline
\end{tabular}

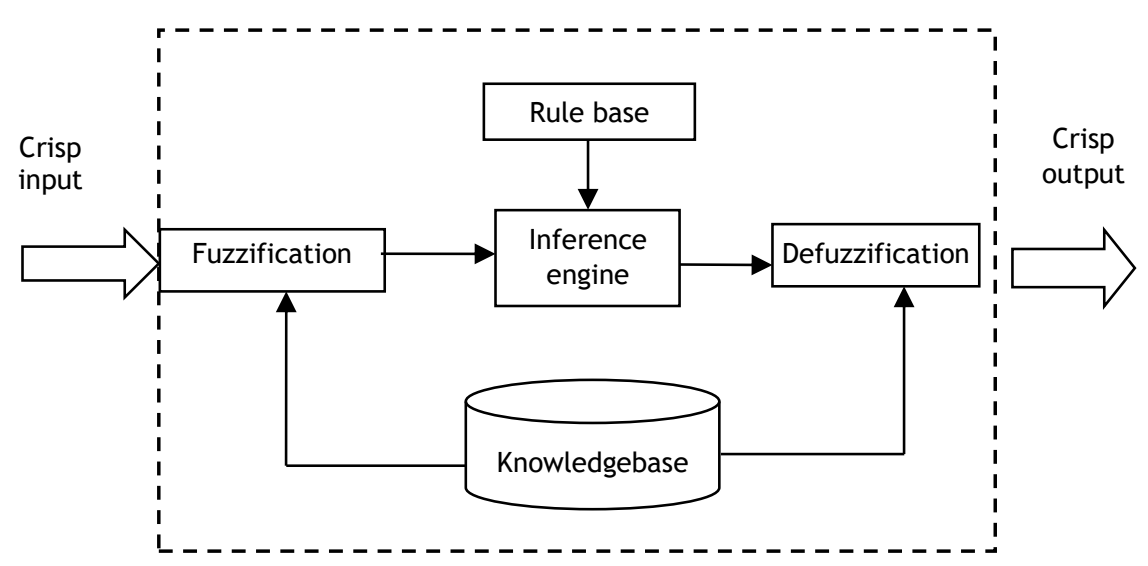

Figure1: Fuzzy inference system

\subsection{Fuzzy inference system}

Hybrid fuzzy approaches are popular among researchers in dealing with a supplier selection problem [2, 3]. Few researchers have applied the fuzzy inference system in addressing the supplier selection problem. Amindoust et al. [32] developed a fuzzy inference ranking model to select sustainable suppliers. Lima Junior, Osiro and Carpinetti [33] presented a fuzzy inference decision method that is used for sorting in the qualification stages and for ranking in the final selection. A rule-based fuzzy inference system model was proposed by Paul [34] to select the most excellent supplier by considering both qualitative and quantitative 
selection criteria. Amindoust [35] calculated the resiliency and sustainability affinity indices of suppliers using a modular fuzzy inference system.

In a fuzzy inference system, a set of logic inference rules in linguistic terms, which form the knowledge base of a fuzzy system, infer output fuzzy variables from input fuzzy variables. The Mamdani FIS system has four parts: fuzzifier, rules, interface engine, and defuzzifier [32], as shown in Figure 1.To build, edit, and view fuzzy inference systems in MATLAB, we use the following tools: fuzzy logic designer, rule editor, rule viewer, and surface viewer. An Evalfis command evaluates the output of an FIS for a given input combination [36].

\section{PROPOSED METHODOLOGY}

This study proposes a novel strategic supplier segmentation methodology. The objective is to select suppliers for the development of agility capability. Using fuzzy inference systems, agility capability and business excellence are assessed. The assessment scores are used to construct the segmentation matrix. The methodology is composed of the five steps set out below.

Step 1. Identify strategic suppliers and formulate an expert team. The first step is to identify the strategic suppliers using the Kraljic portfolio matrix. An expert team needs to be formulated. This is a cross-functional team, with experts from various departments, that does the assessment of various suppliers by consensus.

Step 2. Compute business excellence score. The Singapore Quality Awards business excellence framework is used to assess the suppliers. The expert team assesses each supplier on individual criteria and arrives at a score. The fuzzy inference system processes these crisp inputs and gives the final crisp business excellence score for the supplier. Six totally different fuzzy inference systems are used, with defined membership functions and a knowledge rule base. The expert team develops these fuzzy inference systems using MATLAB. The framework of the fuzzy inference systems (FISs) is shown in Figure 2.

Scores for the criteria of strategy, people, and process are the inputs to FIS 1 . The output of FIS 1 and the customer score are the inputs to FIS 2 . The output of FIS 2 and the knowledge score are the inputs to FIS 3. The output of FIS 3 and the leadership score are the inputs to FIS 4. For FIS 5, customer Results, financial and market results, people results and operational results act as inputs. The inputs to FIS 6 are the outputs of FIS 4 and FIS 5. The output of FIS 6 gives the business excellence score of the supplier. Thus each supplier is evaluated by the fuzzy inference system, and business excellence scores (BESs) are obtained.

Step 3.Compute the agility capability score. The expert team uses the agility capability scorecard developed by the authors to assess the supplier's agility. Five totally different FISs are used. Each system has defined membership functions and a knowledge rule base. The expert team develop these fuzzy inference systems using MATLAB. The framework of the FISs is shown in Figure 2.

The criteria for evaluating the agility capability are grouped into four modules: competency, flexibility, responsiveness, and quickness. For FIS 7 , the inputs are core competency and technology, and the output is competency. The inputs to FIS 8 are machine flexibility, routing flexibility, and material handling flexibility and the output is flexibility. The inputs to FIS 9 are business process integration, empowerment, and knowledge management, and the output is responsiveness. The inputs to FIS 10 are concurrent engineering internal collaboration and external collaboration and the output is quickness. Competency, flexibility, responsiveness, and quickness are the inputs to FIS 11, and the output of FIS 11 is the agility capability score (ACS).

Step 4.Construct supplier segmentation matrix. The segmentation matrix is plotted using the agility capability score on the horizontal dimension and the business excellence score on the vertical dimension. We use segmentation levels of 'low', 'medium' and 'high' for the AC score and the BC score. This deliberation leads to a convenient number of nine segments, as shown in Table 4.

Step 5.Select suppliers for development. The final step is to develop strategies for each segment. Table 4 shows the developed strategies. The segments in the medium category of the AC score and in the medium and high categories of the BE score are those that are most suitable for development. The suppliers in this segment are selected for the development activity. 


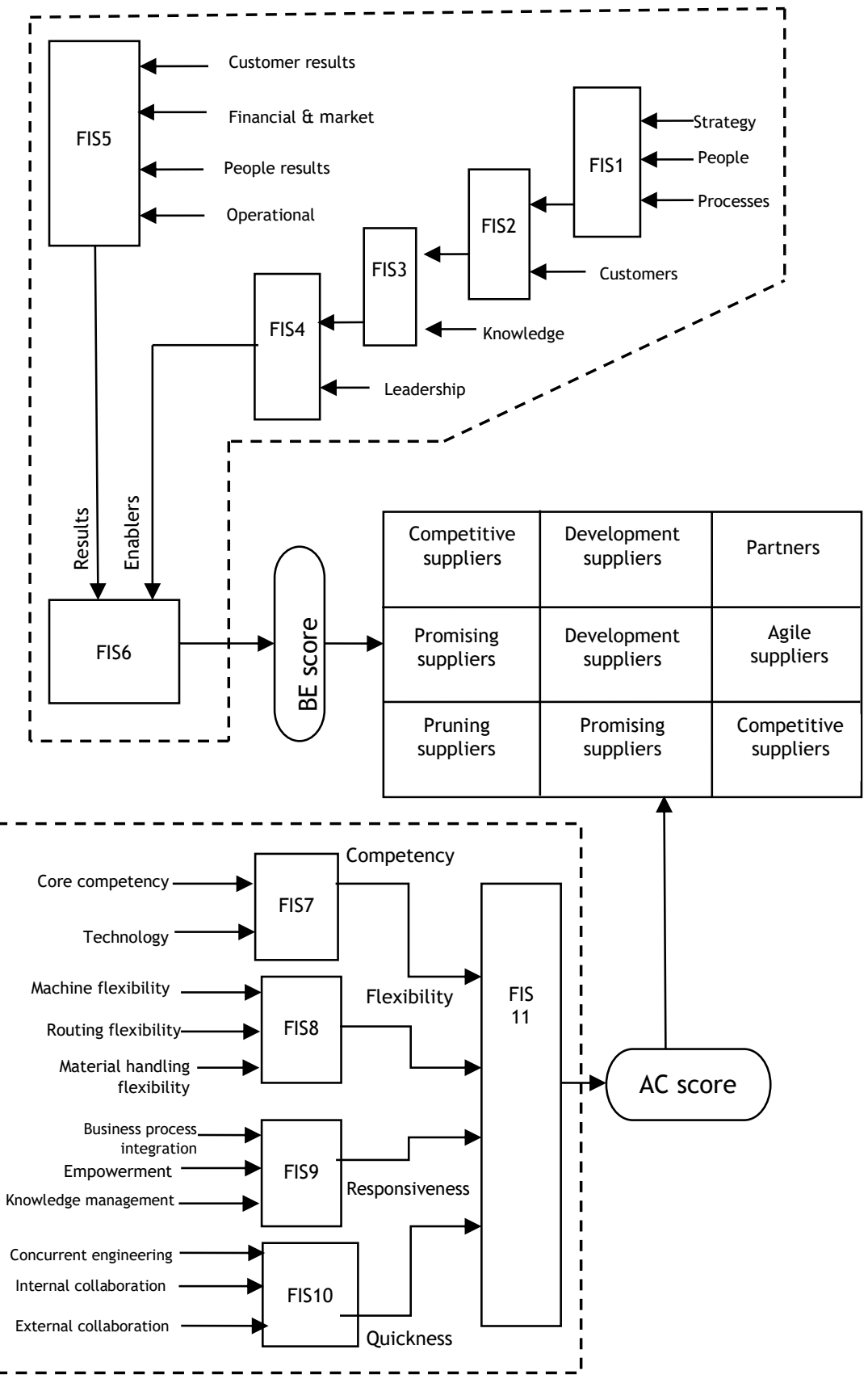

Figure 2: Framework of the supplier segmentation model using FISs 
Table 4: Strategies for supplier segments

\begin{tabular}{|c|c|c|c|c|}
\hline S.No & ACS & BES & Segment & Strategy \\
\hline 1 & High & High & Partners & Strengthen the relationship \\
\hline 2 & High & Medium & Agile suppliers & Agile supplier directs them to improve BE score \\
\hline 3 & High & Low & $\begin{array}{l}\text { Competitive } \\
\text { suppliers }\end{array}$ & $\begin{array}{l}\text { Agile supplier directs them to improve BE score and plan dual } \\
\text { sourcing }\end{array}$ \\
\hline 4 & Medium & High & $\begin{array}{l}\text { Development } \\
\text { suppliers }\end{array}$ & Selected for development programme \\
\hline 5 & Medium & Medium & $\begin{array}{l}\text { Development } \\
\text { suppliers }\end{array}$ & Selected for development programme \\
\hline 6 & Medium & Low & $\begin{array}{l}\text { Promising } \\
\text { suppliers }\end{array}$ & $\begin{array}{l}\text { Direct them to improve BE score and subsequently include them } \\
\text { in the next development phase }\end{array}$ \\
\hline 7 & Low & High & $\begin{array}{l}\text { Competitive } \\
\text { suppliers }\end{array}$ & Direct them to improve AC score and plan dual sourcing \\
\hline 8 & Low & Medium & $\begin{array}{l}\text { Promising } \\
\text { suppliers }\end{array}$ & $\begin{array}{l}\text { Direct them to improve AC score and subsequently include them } \\
\text { in the next development phase }\end{array}$ \\
\hline 9 & Low & Low & Pruning suppliers & Look for alternative suppliers and phase out \\
\hline
\end{tabular}

\section{ILLUSTRATIVE EXAMPLE}

In order to provide insight into the proposed methodology, we introduce an example. This illustrates the segmentation and the selection of suppliers for development. After deliberation with academic experts and supply chain managers, the data in the example was chosen so that it mimicked real-world data. Consider a manufacturing company that is embracing agile strategies in order to be competitive in ever-changing markets driven by customers. One of the important determinants of agility lies in the hands of strategic suppliers. The company was committed to rapid partnership formation with agile suppliers and to enhance its agility. The case company wanted to contribute to the development of its suppliers' agility so that they could become strategic partners. So the objective was to identify strategic agile partners and select suppliers for agility capability development

\subsection{Identify strategic suppliers and formulate an expert team}

We assumed that the company had a list of strategic suppliers that were segmented using the Kraljic matrix. In our study, we identified the top 12 strategic suppliers for segmentation. The suppliers were important in determining the agility of the supply chain. In this example, the authors played the role of the expert members.

\subsection{Compute business excellence score}

The Singapore Quality Award Business Excellence framework was used to assess the identified suppliers. The expert team assessed the suppliers using the BE framework. Scores were given to the suppliers for each criterion through consensus. The scores given are listed in Table 5, and were the crisp inputs of the fuzzy inference system. The membership function and the rule base were determined by the expert team to develop the FIS in MATLAB (supplementary material). The business excellence score was obtained from six cascading fuzzy inference systems. The FIS outputs are listed in Table 6. 
Table 5: Business excellence score given by the expert team for each sub-criterion

\begin{tabular}{rrrrrrrrrrrrrr}
\hline \multicolumn{1}{c}{ Leadership } & \multicolumn{1}{c}{ Customers } & \multicolumn{1}{c}{ Strategy } \\
\hline \multicolumn{1}{c}{ Suppliers } & 1.1 & 1.2 & 1.3 & 2.1 & 2.2 & 2.3 & 3.1 & 3.2 & 4.1 & 4.2 & 4.3 & 4.4 \\
\hline S1 & 32 & 24 & 18 & 16 & 22 & 16 & 26 & 24 & 18 & 14 & 14 & 12 \\
S2 & 42 & 30 & 25 & 25 & 28 & 24 & 30 & 30 & 25 & 14 & 15 & 16 \\
S3 & 40 & 28 & 25 & 25 & 32 & 24 & 34 & 32 & 25 & 16 & 15 & 16 \\
S4 & 44 & 34 & 26 & 26 & 34 & 24 & 34 & 32 & 26 & 16 & 16 & 16 \\
S5 & 40 & 30 & 25 & 25 & 30 & 24 & 32 & 30 & 25 & 16 & 15 & 16 \\
S6 & 28 & 22 & 16 & 16 & 22 & 15 & 27 & 28 & 20 & 16 & 14 & 15 \\
S7 & 30 & 22 & 16 & 20 & 25 & 20 & 20 & 20 & 16 & 12 & 10 & 10 \\
S8 & 10 & 10 & 8 & 8 & 10 & 9 & 10 & 10 & 7 & 4 & 5 & 6 \\
S9 & 30 & 25 & 25 & 24 & 20 & 15 & 30 & 30 & 26 & 16 & 14 & 12 \\
S10 & 20 & 16 & 14 & 20 & 20 & 20 & 20 & 20 & 8 & 8 & 8 & 6 \\
S11 & 30 & 24 & 18 & 16 & 22 & 16 & 22 & 22 & 16 & 12 & 12 & 12 \\
S12 & 40 & 28 & 24 & 24 & 26 & 22 & 26 & 26 & 22 & 14 & 15 & 14 \\
\hline
\end{tabular}

Category

\begin{tabular}{rrrrrrrrrr}
\hline & \multicolumn{4}{c}{ Processes } & \multicolumn{3}{c}{ Knowledge } & \multicolumn{3}{c}{ Results } \\
\multicolumn{1}{c}{ Suppliers } & 5.1 & 5.2 & 5.3 & 6.1 & 6.2 & 7.1 & 7.2 & 7.3 & 7.4 \\
\hline S1 & 18 & 18 & 24 & 24 & 18 & 32 & 26 & 26 & 24 \\
S2 & 26 & 26 & 26 & 30 & 30 & 90 & 105 & 80 & 82 \\
S3 & 26 & 26 & 26 & 30 & 30 & 95 & 98 & 90 & 88 \\
S4 & 28 & 26 & 26 & 32 & 32 & 92 & 108 & 94 & 90 \\
S5 & 25 & 24 & 26 & 30 & 30 & 100 & 94 & 88 & 86 \\
S6 & 22 & 20 & 20 & 18 & 18 & 60 & 75 & 65 & 65 \\
S7 & 18 & 15 & 15 & 20 & 18 & 84 & 74 & 76 & 76 \\
S8 & 7 & 7 & 7 & 10 & 8 & 30 & 25 & 25 & 25 \\
S9 & 25 & 20 & 20 & 18 & 18 & 83 & 75 & 70 & 70 \\
S10 & 12 & 10 & 10 & 20 & 20 & 55 & 55 & 50 & 50 \\
S11 & 16 & 16 & 14 & 20 & 18 & 64 & 80 & 66 & 72 \\
S12 & 24 & 22 & 22 & 28 & 28 & 88 & 102 & 84 & 82 \\
\hline
\end{tabular}

Table 6: Outputs of FIS (business excellence)

\begin{tabular}{crrrrrr}
\hline Suppliers & FIS 1 & FIS 2 & FIS 3 & FIS 4 & FIS 5 & FIS 6 \\
\hline S1 & 160 & 174 & 175 & 190 & 133 & 397 \\
S2 & 234 & 323 & 389 & 510 & 340 & 750 \\
S3 & 236 & 321 & 389 & 510 & 407 & 946 \\
S4 & 237 & 318 & 394 & 504 & 409 & 947 \\
S5 & 235 & 323 & 389 & 510 & 380 & 816 \\
S6 & 172 & 165 & 175 & 190 & 230 & 500 \\
S7 & 160 & 233 & 341 & 281 & 270 & 621 \\
S8 & 40 & 42 & 49 & 48 & 133 & 187 \\
S9 & 203 & 226 & 310 & 365 & 261 & 588 \\
S10 & 160 & 233 & 389 & 365 & 230 & 500 \\
S11 & 160 & 174 & 175 & 190 & 230 & 500 \\
S12 & 185 & 233 & 394 & 511 & 358 & 763 \\
\hline
\end{tabular}

Table 7: Agility capability score given by the experts for each sub-criterion

\begin{tabular}{|c|c|c|c|c|c|c|c|c|c|c|c|}
\hline & \multicolumn{11}{|c|}{ Criteria } \\
\hline & \multicolumn{2}{|c|}{ Competency } & \multicolumn{3}{|c|}{ Flexibility } & \multicolumn{3}{|c|}{ Responsiveness } & \multicolumn{3}{|c|}{ Quickness } \\
\hline Supplier & 1.1 & 1.2 & 2.1 & 2.2 & 2.3 & 3.1 & 3.2 & 3.3 & 4.1 & 4.2 & 4.3 \\
\hline S1 & 50 & 50 & 45 & 35 & 35 & 40 & 25 & 15 & 35 & 20 & 20 \\
\hline S2 & 110 & 110 & 100 & 75 & 55 & 75 & 30 & 30 & 80 & 30 & 30 \\
\hline S3 & 50 & 50 & 40 & 35 & 25 & 40 & 25 & 15 & 35 & 20 & 20 \\
\hline S4 & 100 & 105 & 100 & 75 & 40 & 70 & 25 & 25 & 65 & 35 & 30 \\
\hline S5 & 135 & 135 & 110 & 80 & 70 & 85 & 40 & 45 & 90 & 45 & 40 \\
\hline S6 & 100 & 120 & 100 & 70 & 50 & 65 & 30 & 25 & 70 & 30 & 30 \\
\hline S7 & 110 & 110 & 100 & 75 & 55 & 75 & 30 & 30 & 80 & 30 & 30 \\
\hline S8 & 45 & 50 & 40 & 35 & 30 & 35 & 25 & 15 & 30 & 20 & 20 \\
\hline S9 & 135 & 135 & 110 & 80 & 65 & 80 & 35 & 40 & 90 & 40 & 40 \\
\hline S10 & 60 & 50 & 42 & 34 & 32 & 42 & 24 & 16 & 34 & 22 & 20 \\
\hline S11 & 105 & 110 & 90 & 70 & 50 & 80 & 35 & 35 & 70 & 25 & 30 \\
\hline S12 & 115 & 110 & 95 & 75 & 55 & 75 & 30 & 30 & 85 & 30 & 30 \\
\hline
\end{tabular}




\subsection{Compute the agility capability score}

The expert team decided on the membership function and rule base for assessment, and built the fuzzy inference system in MATLAB (supplementary material). The agility capability of the suppliers was assessed, and scores were given for each criterion. The scores are listed in Table 7. The fuzzy inference system took these scores as crisp inputs. Five modular fuzzy inference systems processed and produced the agility capability score of each supplier. The FIS outputs are listed in Table 8.

\subsection{Construct supplier segmentation matrix}

The agility capability score and the business excellence score were used to construct the segmentation matrix. The scores of the suppliers were scatter plotted. The agility capability score was sorted into three categories: low $(0-400)$, medium $(401-700)$ and high $(701-1000)$. The three categories of the business excellence scores were low $(0-300)$, medium $(301-700)$ and high $(701-1000)$. The suppliers falling into these segments could be easily identified, as seen in Figure 3.

Table 8: Outputs of FIS (agility capability)

\begin{tabular}{cccccc}
\hline Suppliers & FIS 7 & FIS 8 & FIS 9 & FIS 10 & FIS 11 \\
\hline S1 & 150 & 150 & 79 & 100 & 350 \\
S2 & 183 & 234 & 132 & 150 & 619 \\
S3 & 150 & 150 & 79 & 100 & 350 \\
S4 & 165 & 239 & 115 & 121 & 596 \\
S5 & 274 & 271 & 181 & 181 & 896 \\
S6 & 210 & 227 & 100 & 115 & 540 \\
S7 & 183 & 234 & 132 & 150 & 619 \\
S8 & 135 & 150 & 79 & 85 & 350 \\
S9 & 274 & 271 & 179 & 181 & 896 \\
S10 & 150 & 146 & 83 & 97 & 350 \\
S11 & 181 & 177 & 153 & 115 & 583 \\
S12 & 199 & 203 & 132 & 150 & 555 \\
\hline
\end{tabular}

\subsection{Select suppliers for development}

From Figure 3, the suppliers S4, S2, S12, S7, S11, and S6 were identified for development.

\subsection{Results and discussion}

Figure 3 depicts the segments in which each supplier is placed; a separate strategy for each segment is formulated. Supplier S5 is identified as a strategic partner. Supplier S9 is an agile supplier, and is directed to improve its BE score so that it can subsequently become a partner. S1 and S10 are promising suppliers, and are directed to improve their agile capabilities to be included in the next development phase. $\$ 3$ is competitive supplier with a high BE score; if improving its AC score takes a long time or is not feasible, then dual sourcing of the supplied item is considered.S8 is a pruning supplier with low AC and BE scores. An alternative supplier is chosen, and this supplier is phased out. Thus the $3 \times 3$ segmentation matrix, built on the dimensions of the $\mathrm{AC}$ and $\mathrm{BE}$ scores, segments the suppliers, and the suppliers for development are selected.

The Kraljic matrix [12] and Rezaei and Ortt's matrix [13] are two popular approaches to supplier segmentation. From the perspective of supplier relationship management, the Kraljic segmentation matrix has established itself as an excellent tool. From the perspective of supplier development, different approaches are needed. Supplier development activities may be of two types: indirect or reactive, and direct or strategic. The reactive type is oriented to overcome specific performance deficiencies. It is shortterm, tactical, or operational for example, development activities to improve specific criteria such as quality or delivery. For the reactive type, segmentation needs to be based on a performance evaluation. The matrix of Lima and Carpinetti [19] segments suppliers for reactive supplier development.

The strategic type is aimed at improving long-term supplier capability. It is aligned with business strategies such as improving leanness or agility, or greening the supply chain. Rezaei and Ortt's matrix segments suppliers along the two dimensions of capability and willingness. Although supplier willingness is an important factor in supplier development activity, it is difficult to measure, as it is a subjective criterion. 


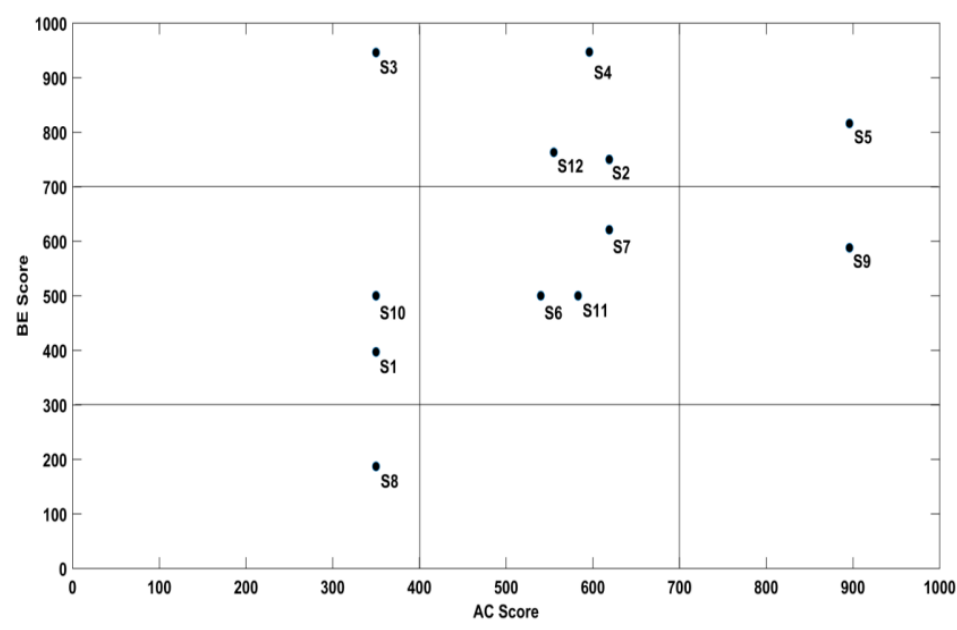

Figure 3: Supplier segmentation matrix

In this study, the willingness dimension is replaced by business excellence, which is about building and fortifying the management systems and processes of a company to improve its performance. It also focuses on creating value for stakeholders. Business excellence models are used to measure how well the core values and concepts are rooted in a company. Companies use BEMs to know and measure which processes need to be enhanced to improve results. The business excellence assessment score acts as an important dimension in the segmentation matrix. The dimension of capability needs to be more specific; for an organisation embracing agile strategy, agility capability is an important dimension of the segmentation matrix. Thus this study introduces two new dimensions into supplier segmentation. A $2 \times 2$ matrix was developed in earlier studies, and in this work a $3 \times 3$ matrix is developed, with nine segments. More specific strategies are delineated.

This study has some managerial implications. The model developed here supports managerial decisionmaking in supplier development. Industries that are interested in developing the agility of their supply chain and planning for supplier agility capability development programmes can use this model directly, as it has strong practical applicability.

\section{CONCLUSION}

This study has presented a new methodology to segment suppliers for development, based on fuzzy inference systems. The main contributions of this work can be summarised as follows:

- $\quad$ This study addresses the crucial decision of selecting suppliers for developmental activity. Recently suppliers have been segmented on the dimensions of capabilities and willingness. For the first time, segmentation has been done using agility capability and business excellence dimensions.

- The segmentation matrix developed in this study not only identifies the development suppliers, but also shows the strategic partners and suppliers who are to be phased out.

- To our knowledge, this is one of the first studies that has used the business excellence model for supplier segmentation.

- The agility capability assessment model was developed after identifying agility capabilities and enablers' criteria from the literature. As it was modelled on the BE framework, experts can assess the agility capability of their suppliers and easily score them.

- $\quad$ This methodology offers the benefits of using fuzzy inference systems. The cascaded FIS approach overcomes the limitation of having to take up more criteria for the evaluation. The proposed method is not limited by the number of evaluated suppliers.

There were some limitations to this study. Although the illustrative example proves the ability of the proposed model to segment suppliers, a case study in a real-world setting would have tested the effectiveness of the model in supplier segmentation. Further research could explore the use of other evaluation techniques and the application of this methodology to segment suppliers based on lean capability or green capability. 


\section{REFERENCES}

[1] Handfield, R.B., Krause, D.R., Scannell, T.V.\& Monczka, R.2000. Avoid the pitfalls in supplier development. Sloan Management Review, 33(2), pp.37-49.

[2] Chai, J., Liu,J.N.K.\&Ngai,E.W.T. 2013. Application of decision-making techniques in supplier selection: A systematic review of literature. Expert Systems With Applications, 40(10), pp. 3872-3885.

[3] Yildiz, A. \&Yayla,A.Y.2015. Multi-criteria decision-making methods for supplier selection: A literature review. South African Journal of Industrial Engineering, 26(2), pp. 158.

[4] Govindan, K., Rajendran,S.,Sarkis,J.\&Murugesan, P. 2015. Multi criteria decision making approaches for green supplier evaluation and selection: A literature review. Journal of Cleaner Production, 98, pp. 66-83.

[5] Rajesh, G. \& Malliga, P. 2018. Selection of suppliers using Swara and Copras-G. International Journal of Enterprise Network Management, 9(2), pp. 169-185.

[6] Bai, C. \& Sarkis, J. 2011. Evaluating supplier development programs with a grey based rough set methodology. Expert Systems with Applications, 38(11), pp. 13505-13517.

[7] Glock, C.H., Grosse,E.H.\& Ries, J.M. 2017. Reprint of "Decision support models for supplier development: Systematic literature review and research agenda".International Journal of Production Economics, 194(August), pp. 246-260.

[8] Krause, D.R., Handfield,R.B.\& Scannell, T.V.1998. An empirical investigation of supplier development: Reactive and strategic processes. Journal of Operations Management, 17(1), pp. 39-58.

[9] Arroyo-López, M. del P.E. \& Ramos-Rangel, J.A. 2018. A methodological proposal to define supplier development programs. Ingeniería, Investigación y Tecnología, 19(1), pp. 25-36.

[10] Dyer, J.H., Cho,D.S.\& Cgu, W. 2012. Strategic supplier segmentation: The next "best practice" in supply chain management. California Management Review, 40(2), pp. 57-77.

[11] Rezaei, J., Wang,J.\& Tavasszy, L. 2015. Linking supplier development to supplier segmentation using best worst method. Expert Systems with Applications, 42(23), pp. 9152-9164.

[12] Kraljic, P. 1983. Purchasing must become supply management. Harvard Business Review, Sep-Oct, pp. 108-117.

[13] Rezaei, J. \& Ortt, R. 2012. A multi-variable approach to supplier segmentation. m, 50(16), pp. 4593-4611.

[14] Lee, J., Cho,H.\& Seog, Y. 2015. Expert systems with applications assessing business impacts of agility criterion and order allocation strategy in multi-criteria supplier selection. Expert Systems with Applications, 42(3), pp. 1136-1148.

[15] Galankashi, M.R., Hisjam,M.\& Helmi, S.A. 2016. Agile supplier selection: A fuzzy analytic hierarchy process (FAHP) approach. Proceedings of the 2016 International Conference on Industrial Engineering and Operations Management, Kuala Lumpur, Malaysia, March 8-10, IEOM Society International, pp. 1033-1040

[16] Rezaei, J. and R. Ortt, 2013. Multi-criteria supplier segmentation using a fuzzy preference relations based AHP. European Journal of Operational Research, 225(1), pp 75-84.

[17] Bai, C., J. Rezaeiand J. Sarkis, 2017. Multicriteria green supplier segmentation. IEEE Transactions on Engineering Management, 64(4), pp 515-528.

[18] Santos, L.F. de O.M., L. Osiroand R.H.P. Lima, 2017. A model based on 2-tuple fuzzy linguistic representation and analytic hierarchy process for supplier segmentation using qualitative and quantitative criteria. Expert Systems with Applications, 79, pp 1339-1351.

[19] Lima-Junior, F.R. and L.C.R. Carpinetti, 2016. Combining SCOR ${ }^{\circledR}$ model and fuzzy TOPSIS for supplier evaluation and management. International Journal of Production Economics, 174, pp. 128-141.

[20] Galo, N.R., Calache,L.D.D.R.\&Carpinetti, L.C.R. 2018. A group decision approach for supplier categorization based on hesitant fuzzy and ELECTRE TRI. International Journal of Production Economics, 202(March), pp. 182196.

[21] Stachowiak, A. \& Oleśków-Szłapka, J. 2018. Agility capability maturity framework. Procedia Manufacturing, 17, pp. 603-610.

[22] Ebrahimpour, H., Salarifar,M.\& Asiaei, A. 2012. The relationship between agility capabilities and organizational performance: A case study among home appliance factories in Iran. European Journal of Business and Management, 4(17), pp. 186-194.

[23] Tseng, Y.H. \& Lin, C.T. 2011. Enhancing enterprise agility by deploying agile drivers, capabilities and providers. Information Sciences, 181(17), pp. 3693-3708.

[24] Wu, C. \& Barnes, D. Barnes, 2010. Formulating partner selection criteria for agile supply chains : A Dempster -Shafer belief acceptability optimisation approach. InternationalJournal of Production Economics, 125(2), pp. 284293.

[25] Mohammady, P. \& Amid, A. 2010. Integrated fuzzy VIKOR and fuzzy AHP model for supplier selection in an agile and modular virtual enterprise application of FMCDM on service companies. Journal of Mathematics and Computer Science, 01(04), pp. 413-434.

[26] Soltan, H. \& Mostafa, S. 2015. Lean and agile performance framework for manufacturing enterprises. Procedia Manufacturing, 2(February), pp. 476-484.

[27] Vinodh, S. \& Aravindraj, S. 2015. Benchmarking agility assessment approaches: A case study. Benchmarking, 22(1), pp. 2-17.

[28] Beikkhakhian, Y., Javanmardi,M.,Karbasian,M.\& Khayambashi, B. 2015. The application of ISM model in evaluating agile suppliers selection criteria and ranking suppliers using fuzzy TOPSIS-AHP methods. Expert Systems with Applications, 42(15-16), pp. 6224-6236.

[29] Kumar Potdar, P. \& Routroy, S. 2018. Analysis of agile manufacturing enablers: A case study. Materials Today: Proceedings, 5(2), pp. 4008-4015. 
[30] Aydin, S., Kahraman,C.\& Kaya, I. 2012. A new fuzzy multicriteria decision making approach: An application for European Quality Award assessment. Knowledge-based Systems, 32, pp. 37-46.

[31] Enterprise Singapore.2019.Business excellence framework. https://www.enterprisesg.gov.sg/-/media/esg/files/quality-and-standards/businessexcellence/be_framework.pdf?la=en.Accessed 11 June 2019.

[32] Amindoust, A., Ahmed,S.,Saghafinia,A.\& Bahreininejad, A. 2012. Sustainable supplier selection: A ranking model based on fuzzy inference system. Applied Soft Computing Journal, 12(6), pp. 1668-1677.

[33] Rodrigues, F., Junior, L., Osiro,L. and Carpinetti, L.C.R. 2013. A fuzzy inference and categorization approach for supplier selection using compensatory and non-compensatory decision rules. Applied Soft Computing Journal, 13(10), pp. 4133-4147.

[34] Paul, S.K. 2015. Supplier selection for managing supply risks in supply chain: A fuzzy approach. International Journal of Advanced Manufacturing Technology, 79, pp. 657-664.

[35] Amindoust, A. 2018. A resilient-sustainable based supplier selection model using a hybrid intelligent method. Computers and Industrial Engineering, 126, pp. 122-135.

[36] Mathworks. https://in.mathworks.com/help/fuzzy/fuzzy-inference-system-modeling.html 